The daily faecal loss was found to be in the range of 1.4-18 $\mathrm{mEq}$ (mean $5.7 \mathrm{mEq}, \mathrm{n}=8$ ). Thus there may be a large variation in faecal losses, and values as high as $26 \mathrm{mEq} / 24$ hours have been recorded (Hayes and Robinson, 1965). Nevertheless, such losses are still small in comparison with the loss to the dialysate which, together with dietary intake, is the major factor in the potassium balance of the regular dialysis patient.

The present study shows that there is a wide range of potassium status in patients with chronic renal failure being maintained with haemodialysis and it is possible that this is, at least in part, related to the variation in potassium status found among non-dialysed patients with chronic renal failure. The absence of a positive relation between the duration of regular dialysis treatment and the total body potassium, together with the balance studies in two patients, indicates that twice-weekly dialysis against a dialysate potassium content of $1 \mathrm{mEq} / \mathrm{l}$. is compatible with the maintenance of potassium balance. A significant advantage of examining potassium status by wholebody monitoring with reference to a normal control group is the simplicity, involving only a single measurement in the patient, and quantification of the degree of abnormality.

We wish to thank Professor $\mathrm{H}$. W. Wilson for his interest and encouragment. This study was supported, in part, by a grant from the Scottish Hospital Endowments Research Trust which is gratefully acknowledged.

\section{References}

Blainey, J. D., Cooke, W. T., Quinton, A., and Scott, K. W. (1954). Clinical

Science, 13, 165 .
Blainey, J. D., and Hilton, D. D. (1970). Annals of The Royal College of Surgeons of England, 47,45

Boddy, K. (1967). British fournal of Radiology, 40, 631.

Boddy, K., King, P. C., Lindsay, R. M., Winchester, G., and Kennedy, A. C., (1972a) British Medical fournal, 1, 140.

Boddy, K., King, P. C., Hume, R., and Weyers E. (1972b). fournal of Clinical Pathology. In press.

Boddy, K., King, P. C., Tothill, P., and Strong, J. A. (1971). Physics in Medicine and Biology, 16, 275.

Corsa, L., Olney, J. M., Steenburg, R. W., Ball, M. R., and Moore, F. D. (1950). Fournal of Clinical Investigation, 29, 1280

Flear, C. T. G., Cawley, R., Cooke, W. T., and Quinton, A. (1958). Clinical Science, 17, 105

Hayes, C. P., and Robinson, R. R. (1965). Transactions. American Society for Artificial Internal Organs, 11, 242

Hughes, D., Williams, R. E., and Smith, A. H. (1967). Clinical Science, 32,

Johnson, J. E., Hartsbuck, J. M., Zollinger, R. M., and Moore, F. D. (1969). Metabolism, 18, 663.

Johnson, W. J., Frohnert, P. P., and Novak, L. P. (1969). Paper read at IV International Congress of Nephrology (Stockholm)

Johny, K. V., Lawrence, J. R., O'Halloran, M. W., Wellby, M. L., and Worthley, B. M. (1970). Nephron, 7, 230.

Moore, F. D., et al., (1954). Metabolism, 3, 334

Morgan, A. G., Burkinshaw, L., Robinson, P. J. A., and Rosen, S. M. (1970) British Medical fournal, 1, 779.

Novak, L. P., Frohnert, P. P., and Johnson, W. J. (1969). Paper read at IV International Congress of Nephrology (Stockholm) O'Toole, J. J., Peterson, R. E., and Weiner, E. V. (1964). Metabolism, 13, 116. Whole Body Counting, I.A.E.A., Vienna, p. 331. London, H.M.S.O.

Seedat, Y.

Talso, P. J., Miller, C. E., Carballo, A. J., and Vasquez, I. (1960). Metabolism, 9, 456.

\title{
Plasma and Urinary Luteinizing Hormone Levels in the Diagnosis of Endocrine Disease
}

\author{
R. WIKRAMANAYAKE， J. R. KEENAN， G. S. SPATHIS， J. D. N. NABARRO， P. J. LEONARD, \\ M. J. GALLAGHER
}

British Medical fournal, 1972, 1, 775-778

\section{Summary}

The diagnostic value of measurements of plasma and urinary luteinizing hormone (LH) has been studied in 209 patients with endocrine disease. In 44 patients puberty was either delayed or had failed to occur. In those with chromosomal abnormalities the LH levels were often within the normal range, whereas those with a pituitary cause usually had low levels. In boys with delayed puberty plasma LH levels rose before physical changes occurred and had prognostic value. In patients with later gonadal failure, men with impotence or infertility, and women with secondary amenorrhoea LH assays proved of little value, although in one case a premature menopause was suspected and six patients with anorexia nervosa had low LH levels.

Edgware General Hospital, Edgware, Middlesex

R. WIKRAMANAYAKE, M.D., M.R.C.P., Locum Consultant Physician

Central Middlesex Hospital, London N.W.10

J. R. KEENAN, M.B., M.R.C.PATH., Consultant Chemical Pathologist

St. Helier Hospital, Carshalton, Surrey

G. S. SPATHIS, D.M., M.R.C.P., Consultant Physician

Middlesex Hospital, London W.1

J. D. N. NABARRO, M.D., F.R.C.P., Consultant Physician

Searle Scientific Services, High Wycombe, Bucks.

P. J. LEONARD, M.SC., M.R.C.PATH., Director of Clinical Chemistry M. J. GALLAGHER, B.SC., PH.D., Biochemist
Sixty patients with disorders of the hypothalamicpituitary area were studied. Levels of LH were measured and considered in relation to the other anterior pituitary hormones. Impairment of LH secretion was one of the first effects on hormone production of disease affecting this area, and this was, of course, most readily detected in postmenopausal women.

The normal ranges of both plasma and urine LH are wide and there seems to be considerable day-to-day variation, especially of urinary output. Several samples should, therefore, be measured if therapeutic decisions are involved.

\section{Introduction}

Knowledge of the levels of follicle-stimulating hormone (FSH) and luteinizing hormone (LH) in plasma or urine is likely to be of value in the diagnosis of a number of patients with endocrine disease. These include patients with delayed sexual maturation, deciding whether it is hypothalamic-pituitary or gonadal in origin and also whether there is just delay or probable failure of gonadotrophin secretion. Gonadotrophin assays may also help in the evaluation of patients with secondary failure of sexual function, secondary amenorrhoea in women, and impotence or infertility in men. Thirdly, gonadotrophin measurements should complement assays of corticotrophin, thyrotrophin, and growth hormone in the assessment of hypothalamicpituitary function.

Methods have now been described for measuring the plasma and urinary concentrations of FSH and of LH (Franchimont, 1970; Lipsett et al., 1970). FSH measurements present considerable practical difficulties but an LH assay has recently been 
made available in this country on a commercial basis, and the present study was started in December 1969 in an attempt to determine how far it would help to solve the diagnostic problems.

\section{Method}

The radioimmunoassay used involved highly purified LH (Dr. Anne Hartree-IRC-2) for labelling and an antibody raised in guinea-pigs to commercially available human chorionic gonadotrophin (HCG), and for plasma assays the standard used was the M.R.C. Research Standard A for human pituitary interstitial cell-stimulating hormone. Plasma results are expressed as $\mathrm{mIU} / \mathrm{ml}$ of 2 nd International Reference Preparation of human menopausal gonadotrophin (2nd IRP HMG), the conversion from M.R.C. Research Standard A being done by bioassay of the latter against 2nd IRP HMG. Urine assays were performed on extracts prepared by alcohol precipitation and the standard used was the 2nd IRP HMG. The assay employed a second antibody, a rabbit anti-guinea-pig serum. The coefficient of variation on a series of repeated samples measured in different assays was $11 \%$. The lowest detectable levels were: in plasma $0.4 \mathrm{mIU} / \mathrm{ml}$ and in urine $1.5 \mathrm{mIU} / \mathrm{ml}$.

The normal values in this assay are shown in Table I. Details of the method are in preparation for publication.

TABLE I-Values in Normal Subjects

\begin{tabular}{|c|c|c|c|c|c|}
\hline & & Mean & S.D. & Range & No. of Samples \\
\hline \multicolumn{6}{|c|}{ Plasma $(m I U / m l)$} \\
\hline Women & $\left\{\begin{array}{l}\text { Follicular and } \\
\text { luteal phases } \\
\text { Pre-ovulatory }\end{array}\right.$ & $\begin{array}{r}7 \cdot 2 \\
35 \cdot 8\end{array}$ & $\begin{array}{l}5 \cdot 3 \\
9 \cdot 7\end{array}$ & $\begin{array}{r}2 \cdot 5-25 \\
15-50\end{array}$ & $\begin{array}{l}357 \text { (including } 9 \\
\text { complete cycles) } \\
21\end{array}$ \\
\hline Men .. & $\begin{array}{l}\text { peak } \\
\text { Postmenopausal } \\
. .\end{array}$ & $\begin{array}{r}28.5 \\
4.9\end{array}$ & $\begin{array}{l}9 \cdot 4 \\
2 \cdot 9\end{array}$ & $\begin{array}{r}14-45 \\
1 \cdot 7-20\end{array}$ & $\begin{array}{l}42 \\
59\end{array}$ \\
\hline \multicolumn{6}{|c|}{ Urine (IU/24 hours) } \\
\hline Women & $\begin{array}{l}\text { Follicular and } \\
\text { luteal phases } \\
\text { Pre-ovulatory }\end{array}$ & $\begin{array}{l}22 \cdot 1 \\
91 \cdot 4\end{array}$ & $\begin{array}{l}14 \cdot 6 \\
24 \cdot 8\end{array}$ & $\begin{array}{c}5-45 \\
40-150\end{array}$ & $\begin{array}{l}10 \text { complete cycles } \\
\text { (195 samples) } \\
46\end{array}$ \\
\hline Men .. & $\begin{array}{l}\text { Postmenopausal } \\
\ldots\end{array}$ & $\begin{array}{l}89 \cdot 2 \\
23 \cdot 9\end{array}$ & $\begin{array}{l}31 ' 5 \\
15.5\end{array}$ & $\begin{array}{c}50-170 \\
4-45\end{array}$ & $\begin{array}{r}36 \\
220\end{array}$ \\
\hline
\end{tabular}

Details of the patients studied are shown in Table II. In 175 of these simultaneous assays of plasma and urine LH were made; in others the measurements were made on the plasma or urine. Multiple assays were made in $\mathbf{8 0}$ of the patients.

TABLE II-Details of 231 Patients Studied

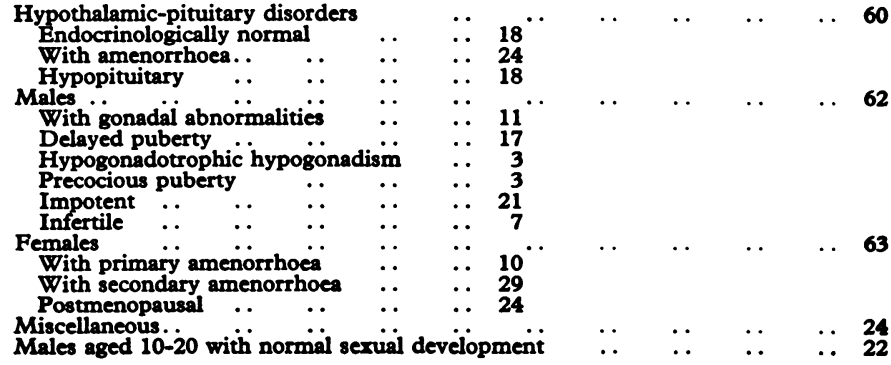

\section{Results}

\section{MALE HYPOGONADISM}

Thirty-one males with primary hypogonadism were investigated. In 11 a chromosomal abnormality or evidence of surgical intervention suggested the underlying cause, and details of these patients are shown in Table III. In many the LH levels were
TABLE III-Details of 11 Male Patients with Primary Hypogonadism Associated with Testicular Abnormality or Damage

\begin{tabular}{|c|c|c|c|c|}
\hline $\begin{array}{c}\text { Case } \\
\text { No. }\end{array}$ & Diagnosis & Age & $\underset{(\mathrm{mIU} / \mathrm{ml})}{\text { Plasma LH }}$ & $\begin{array}{l}\text { Urine LH } \\
\text { (IU/24 hr) }\end{array}$ \\
\hline \multirow[t]{2}{*}{$\begin{array}{r}1 \\
2 \\
3 \\
4 \\
5 \\
6 \\
7 \\
8 \\
9 \\
10 \\
11\end{array}$} & $\begin{array}{l}\text { Kleinfelter's syndrome } \\
\text { Kleinfelter's syndrome } \\
\text { Kleinfelter's syndrome } \\
\text { Male XX } \\
\text { Cryptorchid-operated } \\
\text { Cryptorchid-operated } \\
\text { Cryptorchid-operated } \\
\text { Cryptorchid-operated } \\
\text { Castrate } \\
\text { Castrate on oestrogens } \\
\text { Testicular damage }\end{array}$ & $\begin{array}{l}24 \\
32 \\
48 \\
31 \\
11 \\
11 \\
24 \\
25 \\
36 \\
25 \\
29\end{array}$ & $\begin{array}{r}3 \cdot 3 \\
4 \cdot 1 \\
10 \cdot 6 \\
30 \cdot 1 \\
14 \cdot 5 \\
1 \cdot 1 \\
11 \cdot 0 \\
11 \cdot 2 \\
18 \cdot 8 \\
11 \cdot 0 \\
7 \cdot 5\end{array}$ & $\begin{array}{c}26 \\
25 \\
56 \\
60,78,81 \\
11 \\
30 \\
58 \\
70 \\
\frac{7}{30}\end{array}$ \\
\hline & Normal range & .. & $1 \cdot 7-20$ & $4-45$ \\
\hline
\end{tabular}

within the normal range and did not point to a testicular basis for the condition. Seventeen of the patients were aged 15 to 19 and were referred because of delayed puberty. Plasma LH was measured in 15 of these and the results are shown in Fig. 1; they are compared with the results in 22 boys in whom pubertal

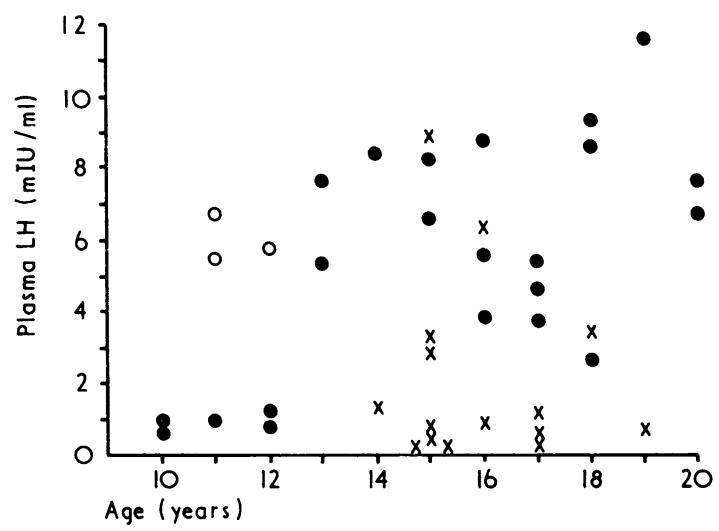

FIG. 1-Plasma LH estimations in 22 boys with normal development $(0), 15$ with delayed puberty $(x)$ and 3 with precocious puberty (o).

changes were occurring normally and in three with precocious puberty. Thirteen of the boys with delayed puberty had low plasma LH levels; the two with higher levels soon began to show pubertal changes. In five of the boys with low levels serial LH measurements were made over a period of up to 18 months and the results are shown in Fig. 2; with the increase of LH pubertal changes became apparent. Only a proportion of patients will improve in this way, and in three older patients, aged 22, 28, and 32 years, with plasma $L H$ levels of $0.3,1.3$, and $<1.3 \mathrm{mIU} / \mathrm{ml}$, a diagnosis of hypogonadotrophic hypogonad-

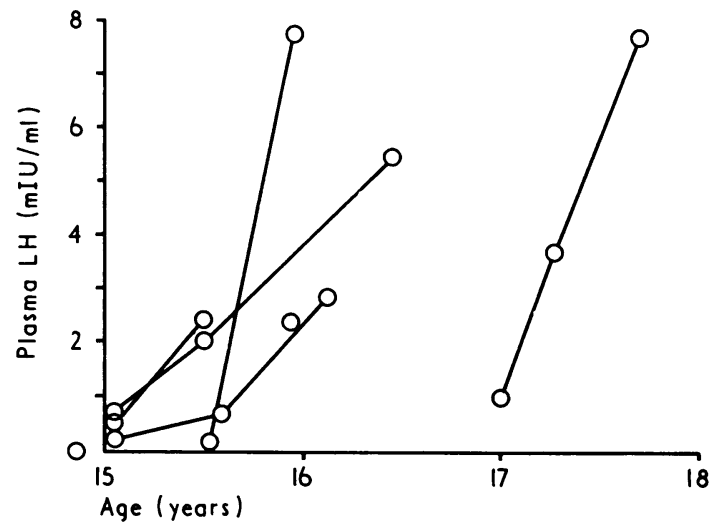

FIG. 2-Serial plasma LH levels in five boys with delayed puberty. 
ism has been made. In 13 of the patients with delayed puberty and 11 of the controls urine $\mathrm{LH}$ assays were obtained; they showed wide variation and were not helpful.

Twenty-one impotent males (including 10 with diabetes mellitus) and seven with infertility were investigated and the results are shown in Table IV.

TABLB IV-Plasma and Urine LH in Men Referred for Impotence or Infertility

\begin{tabular}{|c|c|c|c|c|}
\hline & & $\begin{array}{l}\text { No. of } \\
\text { Cases }\end{array}$ & $\begin{array}{c}\text { Plasma LH } \\
\text { (mIU//ml) } \\
\text { Mean (Range) }\end{array}$ & $\begin{array}{c}\text { Urine LH } \\
\text { (IU/24 hr) } \\
\text { Mean (Range) }\end{array}$ \\
\hline $\begin{array}{l}\text { Impotent diabetics } \\
\text { Impotent non-diabetics } \\
\text { Infertile males }\end{array}$ & $\begin{array}{ll}\because & \cdots \\
\therefore & \cdots \\
\therefore & \cdots\end{array}$ & $\begin{array}{r}10 \\
11 \\
7\end{array}$ & $\begin{array}{l}3.4(0-12 \cdot 5) \\
9.6(0 \cdot 6-30 \cdot 5) \\
3.0(0 \cdot 8-6 \cdot 8)\end{array}$ & $\begin{array}{l}42(2-82) \\
40(2-104) \\
41(2-99)\end{array}$ \\
\hline
\end{tabular}

\section{PRIMARY AMENORRHOEA}

Twelve patients aged 15 to 46 years with primary amenorrhoea and one girl of 13 referred on account of a dental abnormality and found to have a chromosome pattern of gonadal agenesis were studied. In three of these patients a hypothalamic or pituitary tumour was found and they are discussed below. Details of the remaining 10 are given in Table V. In only one patient were the LH levels outside the normal follicular-luteal

TABLE V-Plasma and Urine LH Levels in Patients with Primary Amenorrhoea. Cases 16 and 18 Started to Menstruate Subsequently

\begin{tabular}{|c|c|c|c|c|}
\hline $\begin{array}{l}\text { Case } \\
\text { No. }\end{array}$ & Diagnosis & Age & $\begin{array}{l}\text { Plasma LH } \\
(\mathrm{mIU} / \mathrm{ml})\end{array}$ & $\begin{array}{l}\text { Urine LH } \\
\text { (IU/24 hr) }\end{array}$ \\
\hline \multirow[t]{2}{*}{$\begin{array}{l}12 \\
13 \\
14 \\
15 \\
16 \\
17 \\
18 \\
19 \\
20 \\
21\end{array}$} & $\begin{array}{l}\text { Turner's syndrome } \\
\text { Turner's syndrome } \\
\text { Turner's syndrome } \\
\text { Streak ovaries XX } \\
\text { Delayed menarche } \\
\text { Dwarfism } \\
\text { Delayed menarche } \\
\text { Unknown } \\
\text { Absent uterus and vagina } \\
\text { Absent uterus and vagina }\end{array}$ & $\begin{array}{l}13 \\
15 \\
20 \\
17 \\
18 \\
28 \\
17 \\
46 \\
17 \\
18\end{array}$ & $\begin{array}{l}\overline{15} \cdot 0 \\
22 \cdot 0 \\
31 \cdot 34 \\
1 \cdot 3 \\
7 \cdot 0 \\
4 \cdot 6 \\
2 \cdot 3 \\
2 \cdot 9 \\
5 \cdot 4\end{array}$ & $\begin{array}{r}38 \\
14 \\
35 \\
140 \\
14 \\
37 \\
30 \\
8\end{array}$ \\
\hline & rmol rance & .. & $2 \cdot 5-25$ & $5-45$ \\
\hline
\end{tabular}

phase range. This young woman (Case 15) had a normal karyotype (Mr. R. Meredith) but typical streak ovaries were seen, and biopsy specimens were taken, on laparoscopy (Mr. S. J. Steele). In Cases 16 and 18 menstruation started after the investigations, at ages 18 to 19 . The diagnosis in Case 17 remains obscure, and Case 19 had been seen for another condition and further investigation is not proposed.

\section{SECONDARY AMENORRHOEA}

Forty-two patients under the age of 43 with secondary amenorrhoea were studied. In 13 of these there was a pituitary tumour

TABLE VI-Details of Plasma and Urine LH Levels in Patients with Secondary Amenorrhoea. Normal Ranges for Follicular and Luteal Phases: Plasma 2·5-25 $\mathrm{mIU} / \mathrm{ml}$ and Urine 5-45 IU/24 hours

\begin{tabular}{|c|c|c|c|c|c|c|c|}
\hline $\begin{array}{l}\text { Case } \\
\text { No. }\end{array}$ & Age & $\underset{(\mathrm{mIU} / \mathrm{ml})}{\text { Plasma LH }}$ & $\begin{array}{l}\text { Urine LH } \\
\text { (IU } / 24 \mathrm{hr} \text { ) }\end{array}$ & $\begin{array}{l}\text { Case } \\
\text { No. }\end{array}$ & Age & $\underset{(\mathrm{mIU} / \mathrm{ml})}{\text { Plasma LH }}$ & $\begin{array}{l}\text { Urine LH } \\
\text { (IU/24 hr) }\end{array}$ \\
\hline $\begin{array}{l}22 \\
23 \\
24 \\
25 \\
26 \\
27 \\
28 \\
29 \\
30 \\
31\end{array}$ & $\begin{array}{l}16 \\
18 \\
19 \\
20 \\
21 \\
21 \\
22 \\
22 \\
25 \\
25 \\
27 \\
29 \\
30 \\
31\end{array}$ & $\begin{array}{r}15.1 \\
1.6 \\
23 \\
3.6 \\
7.5 \\
17.0 \\
2.8 \\
<0.8 \\
4.2 \\
3.4 \\
4.9 \\
1.5 \\
4.0 \\
4.2 \\
8.8 \\
65 \\
\frac{65}{2.2}\end{array}$ & $\begin{array}{r}34 \\
11 \\
47 \\
19 \\
11 \\
50 \\
<\begin{array}{r}3 \\
54 \\
10 \\
52 \\
6\end{array} \\
\left\{\begin{array}{r}30 \\
38 \\
\overline{41} \\
74\end{array}\right.\end{array}$ & $\begin{array}{l}36 \\
37 \\
38 \\
39 \\
40 \\
41 \\
42 \\
43 \\
44 \\
45 \\
46 \\
47 \\
48 \\
49 \\
50\end{array}$ & $\begin{array}{l}32 \\
32 \\
34 \\
35 \\
42 \\
22 \\
28 \\
36 \\
38 \\
19 \\
19 \\
19 \\
20 \\
23 \\
26\end{array}$ & $\left\{\begin{array}{r}6.6 \\
15.0 \\
1.8 \\
\frac{3.3}{3.3} \\
25.7 \\
3.3 \\
4.7 \\
3.2 \\
66 \\
72 \\
<0.8 \\
<0.8 \\
<1.0 \\
<3.3 \\
<0.4\end{array}\right.$ & $\begin{array}{r}- \\
7 \\
1 \\
13 \\
13 \\
29 \\
18 \\
52 \\
32 \\
241 \\
357 \\
1 \\
4 \\
34 \\
7 \\
30 \\
16\end{array}$ \\
\hline
\end{tabular}

and they are discussed below. The results in the other 29 are shown in Table VI. Case 41 had mild congenital adrenal hyperplasia, not on treatment; Case 42 had Cushing's syndrome, without evidence of pituitary abnormality; Case 43 had multiple endocrine deficiencies due to autoimmunity; and Case 44 had undergone oophorectomy and was on oestrogen replacement. Cases 45 to 50 had anorexia nervosa. One patient (Case 33) aged 29 had a high plasma LH level suggesting a premature menopause. The results shown in Table VI emphasize the variations of plasma LH that may be found and lack of correlation between plasma and urine levels.

\section{HYPOTHALAMIC-PITUITARY DISORDERS}

Sixty patients with organic disturbances of the hypothalamicpituitary area were investigated. All except five of these had tumours of the pituitary gland, in 21 associated with acromegaly and in three associated with Cushing's syndrome. There were 24 men and 36 women. Three of the women presented with primary amenorrhoea and seven with secondary amenorrhoea although 13 actually had secondary amenorrhoea on questioning and a further 11 were postmenopausal. Plasma and urine LH levels are shown in Fig. $3 \mathrm{~A}$ and $\mathrm{B}$. In the patients with pan-
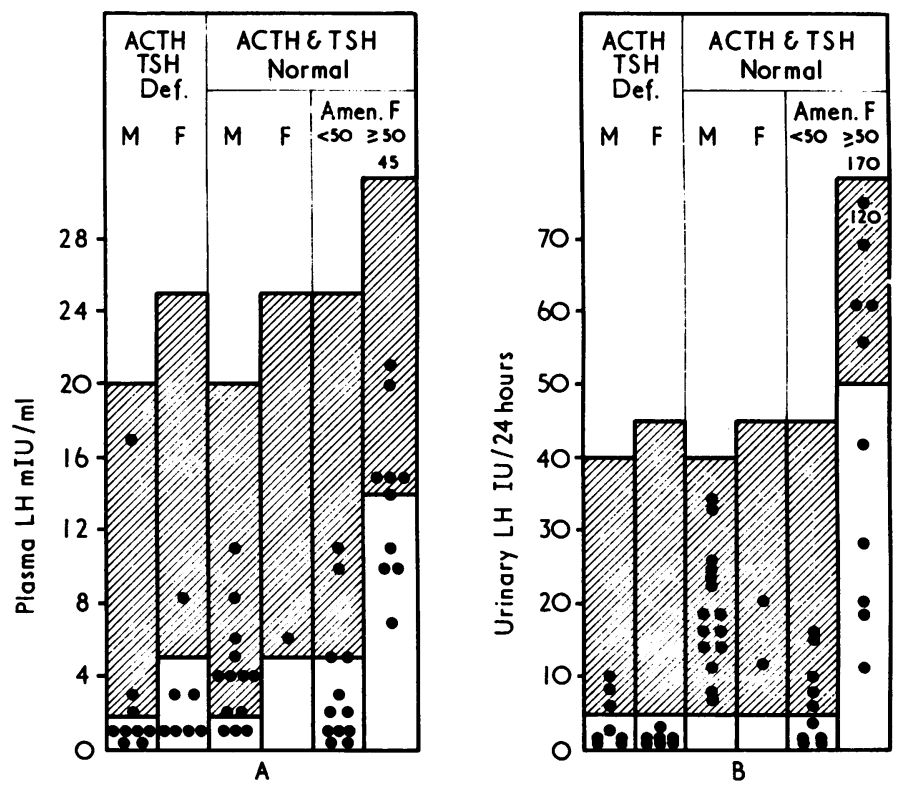

FIG. 3-Plasma (A) and urine (B) LH measurements in patients with hypothalamic-pituitary area disorders. The columns show men and women with hypopituitarism, men and women with normal endocrine function, and amenorrhoeic women (amen. F) subdivided into those under 50 years of age and those aged 50 and over. Shaded areas indicate normal ranges for men, follicular and luteal phase for women under 50, and postmenopausal levels for women aged 50 and over.

hypopituitarism the $\mathrm{LH}$ levels were usually at the lower limit of normal or below, although there were two patients with significant amounts of $\mathrm{LH}$ in the plasma. Men not requiring replacement therapy had normal LH levels, apart from three in whom plasma LH was subnormal. The three menstruating women had normal levels.

Amenorrhoeic women aged under 50 and 50 and over are shown separately and the results compared with those of normal women in the follicular or luteal phases and after the menopause. The younger women showed a larger proportion of subnormal results. The three young women with primary amenorrhoea due to hypothalamic or pituitary disorder had plasma LH levels of $1.9,<0.8$, and $1.5 \mathrm{mIU} / \mathrm{ml}$ and urine $\mathrm{LH}$ outputs of $6.0,2.0$, $2.4 \mathrm{IU} / 24$ hours. Of the 60 patients in this section, $51 \mathrm{had}$ simul- 
taneous plasma and urine LH estimations. Good agreement was obtained in 36 patients, mostly in the panhypopituitary and normal groups. Discordant results were encountered among the amenorrhoeic women under 50, five of whom had normal urine but low plasma levels and three the opposite.

Serial plasma or urine LH measurements were made on 11 patients having surgical treatment (five acromegalics, five with chromophobe adenoma, and one with chordoma). In three the LH levels were higher after operation, in six there was a fall, and in two no obvious change. The three patients in whom the LH levels rose had transsphenoidal hypophysectomies for acromegaly (Mr. R. A. Williams).

\section{Discussion}

In the investigation of patients with primary gonadal failure published data available suggest that FSH measurements are of more value than $\mathrm{LH}$ estimations in the younger age groups (Franchimont, 1970; Penny et al., 1970). In older patients serum $\mathrm{LH}$ levels above the normal range have been found (Anderson et al., 1971). The figures given in Table $\mathrm{V}$ for patients with ovarian agenesis were much higher than those obtained in three young women with primary amenorrhoea due to a hypothalamic-pituitary area neoplasm. Of the four men with chromosomal abnormalities only one had an LH level suggestive of a primary gonadal dysfunction. We have studied one young man with primary hypogonadism associated with hypopituitarism and diabetes insipidus. He had a very low urinary LH output but an unexplained high level of plasma LH.

The results of plasma LH assays in the normal boys and those with delayed puberty suggest that the assay may be helpful in this situation. If there is an appreciable amount of $\mathrm{LH}$ present, provided any chromosomal abnormality is excluded, it may be predicted that pubertal changes will soon appear. Serial estimations may show increase over a period of a few months. In the boys aged 17 and over with low levels hypogonadotrophic hypogonadism may well be present. Many of these boys with delayed puberty are also dwarfed; this may be due to lack of pubertal growth spurt or to actual deficiency of growth hormone (GH). Patients with persistent delay have had insulin hypoglycaemia tests done, and in two showing lack of gonadotrophin and GH careful studies have been undertaken to exclude a hypothalamic-pituitary area neoplasm.

In women with uncomplicated secondary amenorrhoea 9 out of 17 had plasma $\mathrm{LH}$ concentrations below the normal range. In anorexia nervosa the plasma and urine $\mathrm{LH}$ levels were low. Results above normal suggest either a premature menopause or the possibility of a Stein-Leventhal syndrome. It is certainly necessary to consider the figures obtained in relation to vaginal smear cytology and in some cases laparoscopy may also be required before a final diagnosis is made. In the men with impotence the results were very variable; the diabetics tended to have lower plasma LH concentrations, and in most of these the urinary testosterone excretion (Miss Audrey Moxham) was also low. The impotent non-diabetics tended to have higher levels of both. The urinary assays were performed on single samples only and, as indicated below, this is probably unreliable. LH assays have not so far contributed to the investigation of patients with infertility although probably FSH assays will indicate the stage of arrest of spermatogenesis if this is present (Franchimont, 1971).

In patients with hypothalamic-pituitary disturbance the estimation of plasma LH is of undoubted value. Low levels were obtained in most of the patients with hypopituitarism, in women with amenorrhoea but normal TSH and ACTH production, and in a proportion of postmenopausal women. It was of particular value in screening the latter group. Evidence to date suggests that LH is one of the first hormones to be lost in pituitary dysfunction due to hypothalamic-pituitary disorders. Single urine LH assays were sometimes misleading. LH determinations before and after clomiphene administration may be a better indication of hypothalamic-pituitary function (Newton et al., 1971).

Assays of gonadotrophins are in a developmental stage. The choice of suitable standards for plasma and urine assays is still a matter for discussion and probably the results obtained in the various clinical situations will also depend on the particular antibody being used. Any figures for normal range and assessment of diagnostic value must specify standards, materials used for iodination, and antibody. In men and in women apart from the ovulatory peak the plasma $\mathrm{LH}$ seems to be reasonably constant, although it is probably advisable to have two or three estimations in any particular patient. M. J. Gallagher and M. Tidd (unpublished) found that in normal men serial urine assays give results over a wide range. It would therefore seem necessary to have serial assays before attaching diagnostic significance to the results of urine LH output estimations.

At the time of this investigation Dr. Wikramanayake was Nuffield Research Fellow.

\section{References}

Anderson, D. C., Marshall, J. C., and Fraser, T. Russell (1971). Proceedings of the Royal Society of Medicine, 64, 1265

Franchimont, P. (1970). In Reproductive Endocrinology, ed. W. J. Irvine. Edinburgh, Livingstone.

Franchimont, P. (1971). Sandoz Lecture at the Royal College of Physicians

Lipsett, M. B., Cargille, C. M., and Ross, G. T. (1971). Annals of Internal Medicine, 72, 933.

Medicine, 72, 933.
Newton, J., Ramsay, I., and Marsden, P. (1971). Lancet, 2, 190.

Pewton, J., Ramsay, I., and Marsden, P. (1971). Lancet, 2, 190. R. M. (1970). Fournal of Clinical Investigation, 49, 1847. 